\title{
THE METHODOLOGY OF VALORISING AND ASSESSING LANDSCAPE
}

\author{
Urszula Litwin', Stanisław Bacior', Izabela Piech² \\ 1 Department of Agricultural Land Surveying, Cadaster and Photogrammetry, Faculty of Environmental \\ Engineering and Land Surveying, Agricultural University of Cracow, Balicka 253a, 30-149 Kraków, Poland, \\ e-mail: urszulalitwin@wp.pl,rmbacior@cyf-kr.edu.pl,rmpiech@cyf-kr.edu.pl
}

Received: 2016.10.15

Accepted: 2016.11.16

Published: 2017.01.01

\begin{abstract}
Landscape evaluation process requires access to particular information resources making it possible to regionalize (divide into zones) the area under investigation. Thus, the starting point is landscape assessment and evaluation followed by regionalization. As a result of this step, we determine certain areas that are homogenous with regards to their landscape assets
\end{abstract}

Keywords: assessing landscape, structure of rural areas, spatial planning of rural areas.

\section{INTRODUCTION}

Rural areas - all the space remaining outside the borders of towns and cities, which is neither urban nor industrial. The functions of rural areas are as follows: agricultural, silvicultural, recreational, and ecological. Rural areas are subject to transformations caused by various mechanisms: political (system, agrarian policy), demographic (among other things, labour force supply), or market (the demand for specific products, etc.) [11].

A qualitative and quantitative increase in agricultural production can be achieved by properly arranging agrarian structures; and, properly arranged agrarian structures result in organizing landscape structures. Here, it should be stressed that natural landscape and cultural landscape, if correct from the aesthetic point of view, can largely be a result of adequately selected forms of farming and managing in agriculture. Eco-development of rural areas is a concept aiming at determining and setting the tempo, the targets, and the socio-economic developmental means at hand, with which the natural environment becomes destroyed [15]. Studying and recognizing the functional structure of rural areas, including the factual, content-related interpretation of its spatial diversification, can appear useful when determining correct and acceptable ways of switching from the existing to desirable management, thus, to the spatial planning of rural areas [23].

\section{LITERATURE OVERVIEW}

For the first time, the term "landscape" appeared in the form used until the present day in Old German, as early as in the $8^{\text {th }}$ century, as landschaft [6]. The meaning of this word can be decoded by comparing it with the then existing Latin equivalents. Originally, the word "landscape" (landschaft) meant a unit of space in the political and natural-geographical sense. It also could mean the population living in a certain area. Owing to the evolution of the word "landscape" in the German language, with time, it took on an accepted and legal meaning used to describe a region [2].

When describing the evolution of landscape architecture, it is to be remembered that this scientific branch is the only one of its kind since it has cultivated two archetypes of space in parallel: a garden (or a country park) and a town. The first archetype: the garden (the country park) is a symbol of nature whereas the town is a symbol of man's work. The skills of those gardeners and architects have improved over the ages. However, the new type of specialist, landscape architect, could appear and be established only when the subject of the gardener's and architect's work had achieved a certain scale, and their customer was not a single, even most powerful and mighty investor, but a collective ownership, sometimes the entire community or society [8]. 
Landscape architecture is a profession that makes it possible to create natural and cultural beauty. Though, along with the expansion of urbanization processes and shrinkage of its natural background, the traditionally accepted work of architect and gardener needs to gain a new aspect in the form of overall approach to the problems being solved, covering both the form and background. It was the awareness of limits existing in the ecosphere and of interrelations, including aesthetic interrelations, among all the human actions that bore the need to treat the composition factor holistically. The development of democracy meant the number of beneficiaries multiplied as well as their role in space-related decisions. Landscape, being a public good, could not be shaped solely by applying elitist-philanthropic procedures.

The current state of research presents us with six main definitions of landscape. Each of them is laden with professional attitudes of the specialists that have developed it. Additionally and most frequently, each of them is a mixture of major interpretations of this word.

According to Wolski, there are definitions of landscape, in which the landscape is formulated and expressed as a concept [28]. Thus, we can find the following definitions:

- general definitions,

- definitions applied to name a certain fragment of the Earth's surface,

- definitions determining the physiognomy of the Earth's surface,

- definitions determining a subjective reproduction of geo-complex,

- definitions determining the system of constituents of the geographical system.

However, it seems that the second and third way of defining landscape could be described as geographical, the fourth represents an aesthetic approach, and the fifth a nature-related approach [2].

The colloquial language and, subsequently, the artistic language, used the notion of landscape in the sense of a scenery/vista to illustrate picturesque views of the Earth's fragments and treated it as an element or a separate object of artistic expression. For the first time, landscape appeared in the artistic-aesthetic sense of the scenery/vista in 1518.

Regardless of what we understand as landscape, it is one of the aspects within the environment which are not treated as free elements in and by the modern society anymore. Yet, it does not exist separately from a specific, fixed location where its observer is situated. Though, all the environmental parameters that constitute landscape exist objectively and independently of its observer, the value of landscape, usually identified with the landscape's aesthetic assets, is closely related to its observer. These assets are, of course, inherent features of the landscape, to a certain degree, and they do not exist independently and objectively. Usually, a significant level of urban development must be reached to make it possible for a potential observer to (be prepared) to identify aesthetic assets of the environment that we usually label as landscape [2].

Based on specialist literature [24], the following classification of landscape definitions landscape could be suggested. Thus, landscape could be:

- a general concept,

- a geographical concept,

- a nature-related concept;

- an aesthetic concept,

- a socio-cultural concept (historical concept).

According to Berninger [6], we can distinguish two forms as far as the geographic concept of landscape is concerned:

- landscape as an interrelated collection of elements within certain fragment of Earth, often described as "a geographical appearance of landscape";

- landscape as a certain spatial individual, provided such an individual could be differentiated from the overall-geographical point of view when a larger area of Earth would be divided.

Within the geographical aspect, we can also find certain other definitions of landscape:

- the definition developed by Ritter (the second half of the $19^{\text {th }}$ century): landscape is "a specific form of a given land" [21];

- the definition developed by Troll: landscape is "a part of Earth's surface, which - owing to three factors: external appearance, collaboration among phenomena, and external relations (situation) constitutes a spatial unit of a particular, specific character" [14];

- the definition developed by Humboldt (the $19^{\text {th }}$ century) defines landscape as "a complex of features of a given district " [21];

- Kondracki's definition [12] reads that natural landscape is a physiognomic type of a terrain showing its own peculiar structure and con- 
sisting of interconnected surface features and its lithographic composition, water conditions, biocoenotic and soil conditions of the local climate, and, also, those effects of the human management and actions that express modified natural conditions [12];

- Przewoźniak's definition [19] describes landscape as a system of functionally interconnected abiotic and biotic components and a system of spatial units created by them existing in reality (morphological parts of landscape and physical-geographical regions) that are hierarchically and functionally interrelated [19].

The first nature-related definition of landscape in Poland was published in 1912. At the same time, it was the first definition of landscape in Polish scientific vocabulary. It was developed by Smoleński, who described natural landscape as a set of phenomena representing the natural environment and remaining under mutual relationships and mutual conditions formed during the long period of development as a result of free actions of natural forces [22].

The following definition can be also classified under this heading:

According to Wodziczko's definition, landscape represents the entire nature within a limited fragment of Earth's surface, whose state of equilibrium is a result of ongoing self-regulating processes [27].

The following authors describe landscape from the aesthetic point of view:

- Szczęsny described landscape as the whole of the nature including elements incorporated by man on a naturally limited fragment of the Earth; this whole is assessed as a system of natural conditions and represents the predetermined and external aesthetic as well as scenic features $[24,25]$;

- Łuczyńska-Bruzda depicts landscape as the whole of spatial phenomena formed on the Earth's surface both by nature and by cultureoriented actions of man [17],

- Bogdanowski [7] writes that „...landscape includes such notions as: micro-area, limited ... to the size of a forest clearing ... as well as an open macro-structure of fields, forests, and original nature in total. Landscape constitutes the broadest concept of a spatial form ever created by nature and mankind. Landscape is nothing but the physiognomy of the environment."
- Bartkowski $[4,5]$ claims the existence of two meanings of the term "landscape": in the colloquial, common sense of the everyday language (etymologic), referring to the physiognomy of the given material perceived by human senses, which is usually comprehended as the secondary sense, attached to the first sense appearing in encyclopaedias always in the first place; in the special sense, geographic that refers to a set of material objects connected by a geo-complex. This author suggests that a geo-complex, comprehended as a set of physically existing material objects, is a source of diverse signals sent by those objects by electromagnetic waves, acoustic waves, by clouds of chemical compounds, dust clouds, special forms of heat energy sensed by man through, for instance, skin. We perceive and comprehend all those elements to be a landscape. Thus, the geo-complex perceived is a landscape $[4,5]$.

- Patoczka defines landscape as a sum of phenomena perceived at any moment and at any place, as a physiognomy of the existing or imagined surroundings [18].

- Böhm and Patoczka believe that we usually associate landscape with the image of surroundings formed by nature and improved by people; landscape is also construed as a physiognomy of the surroundings that have been transformed either for functional or aesthetic purposes [9].

- Wolski described landscape as a system of natural physical objects plus cultural physical objects influencing, at the same time, the natural physical objects; those objects together make space complete and are a source of cognition, reflection, and aesthetic experience [28].

- Hopfer treats landscape as a term belonging to the domain of nature and referring to basic components of the geographic and natural environment; the term that also includes external scenic features and aesthetic values which seem characteristic for a given area [10].

- According to Bajerowski, Senetra, and Szczepańska, landscape is an external (visual) expression of the current (being analyzed) condition of the geographic environment in which the ongoing processes form characteristic features; those features determine the category, condition, and type of a given landscape. The category of landscape is determined by spatial factors, such as: topographic features, 
ground cover, or hydrologic network, and the condition of landscape is determined by historical (time-depending) factors, for example by individual phases of man's development and the intensity of man's activities. The type of landscape is determined by the function of a given area [2].

\section{DESCRIBING SEVERAL SELECTED METHODS OF LANDSCAPE ASSESSMENT}

Landscape evaluation process requires access to particular information resources making it possible to regionalize (divide into zones) the area under investigation. Thus, the starting point is landscape assessment and evaluation followed by regionalisation. As a result of this step, we determine certain areas that are homogenous with regards to their landscape assets. In order to "zone" a given area (divide the area into zones) landscape features must be selected to create a basis for this process. Choosing a specific variant of zoning does not depend on the environment but exclusively on the authors conducting the zoning procedure.

\section{Bajerowski's Method of Value Matrix}

This method assumes the use of information contained in the generally available maps [3]. Thus, in this method, first of all, topographic maps and maps of land records are analyzed. Aesthetic value of a given landscape is a result of specific and unique configuration of the characteristics of this area. It is possible to identify many of those space characteristics and make an inventory of these in the office, studio, etc., while analyzing the contents of cartographic materials. There are many possibilities of carrying out these cartographic investigations. One of them is a mathematical-statistical analysis of maps which consisting in the study of phenomena by applying "networks of basic assessment fields" to compile (collect) information. A certain figure that determines the aesthetic value of landscape can be assigned to each basic field and such an aesthetic value of landscape is created by the above mentioned specific configuration of space characteristics occurring within the area covered by this "basic assessment field".

By superimposing networks of basic fields of a given area, it is possible to construct an isarith- mic map illustrating the intensity of a given phenomenon. An assumption is possible that the aesthetic value of landscape is inversely proportional to the degree of landscape devastation. The feature of each space creating an aesthetic value of landscape gives rise, to a greater or lesser extent, to the need for launching repair means. This supposition is supported by the fact that, practically, no typical natural landscapes exist anymore and cultural landscapes prevail. Furthermore, the real estate market trades almost exclusively in properties (lands) creating cultural landscapes.

This is why the intensity of occurring space features which generate the need for landscape repair could be a proper measure of the real value of landscape. The higher the need for repair works the lower the aesthetic value of a landscape. Such an approach is justified as long as there is a certain set of repair measures to be successfully applied to the reclamation of landscapes.

It was assumed that the basic fields should cover an area of about 15 ha in size. The author determined this size level after a thorough review of the relevant literature; on a map at a scale of 1:10 000, a side of a 16-ha square equals $400 \mathrm{~m}$ $(4 \mathrm{~cm})$ [2]. The next step is to build a matrix of landscape aesthetic value. To construct such a matrix, it is indispensable to assume that a given area feature, and, at the same time, one of the elements of the general aesthetic value of the area's landscape, generates a need for carrying out at least one repair job $\left(Z_{\mathrm{i}}\right)$. If the parameters of a given feature are "negative", $Z_{i}$ will change them into positive parameters in the sense of aesthetic value, and if they are "positive", Zi will hold them at the former level and prevent this aesthetic value from deteriorating. Each feature can generate needs for diverse repair jobs $\left(\mathrm{Z}_{\mathrm{i}}\right)$ and for various ranges of such jobs.

Let us assume that an inventory matrix (I) is compiled as a result of the created inventory of terrain's features. Its rows inform about the occurrence of a given feature in all the basic fields, and its columns - about the occurrence of features in a given field (whereas the occurrence of features is denoted by " 1 ", and its absence - by " 0 "). This inventory matrix (I) will be a zero-one geographic matrix containing information what features occur in what basic fields. In order to determine aesthetic assets of landscape, a matrix (W) should be constructed; its elements are obtained by multiplying the transposed matrix of a "P" landscape aesthetic value by an "I" inventory matrix (1) 


$$
\mathrm{P}^{\mathrm{T}} \mathrm{x} \mathrm{I}=\mathrm{W}
$$

The value of landscape in the specific basic field is a sum of "output" values contained in the (P) matrix with regard to those features, which are present in this specific field.

The first pattern of the theoretical value of landscape will have the following form:

- I - very valuable landscape: $\leq 100$,

- II - valuable landscape: 101-238,

- III - mediocre landscape: 239-375,

- IV - landscape of little value: $\geq 376$.

Studies performed on some testing areas [3] allowed for a conclusion that the practical, maximum value of landscape rated by points is, in fact, much lower than 700 points. In the case of a rather mediocre object of study, the actual maximum value rated by points amounted to $39 \%$ of the theoretical value $(\geq 376)$, and the actual maximum number of features registered in the basic fields did not exceed $33 \%$ of the theoretical figure. Therefore, it is more adequate to assume limits of the ranges created on the basis of this maximum practical value $(\geq 700)$

The second scheme produces the following range limits:

- I - very valuable landscape: $\leq 42$

- II - valuable landscape: 43-112

- III - mediocre landscape: 113-175

- IV - landscape of little value: $\geq 176$.

Owing to the fact that a cartographic method with a regular network of basic fields was employed to perform the study in question, as was the procedure described above, the results of the conducted studies can be presented in the form of an isarithmic map of landscape aesthetic value.

From the point of view of dependency between landscape aesthetic value and the market value of the area characterized by this landscape, it is much more justified to draw up a map with zones of landscape values whose assessment marks are rated by points of this value. Thus, it is suggested to make zones within the four categories presented and then to assign an assessment mark expressed in points to those determined zones; the assessment mark would be an average value of points rated to the basic fields covered by the given zone [2].

\section{Wejchert's Method of Impression Curve}

A method of impression curve is a graphic representation of tensions of impressions and emotional experiences landscape watchers feel as they move along the time-space route. While moving, we feel diverse emotional tensions connected with aesthetic aspects of the observed environment. A landscape watcher registers subsequent images at certain time intervals closely interrelated with the configuration and shape of the space he goes through. Time and space are inseparable in those systems.

Landscape consists of numerous and diverse scenic views perceive by watchers while moving along a certain route. They classify and organize these views subconsciously. Of course, those scenic views are smaller and poorer in monotonous and uniform systems, whilst larger and stronger in rich and complex areas. Although experiences, feelings, and assessments of such watchers are subjective, it is possible to assume that there is an obvious group of watchers who react to perceived views in the same way; and a graph of deviations from an average reaction will be close to the normal distribution curve. Thus, we should construct the predicted curve of impressions as an illustration of standard impressions and no unit of measure can be determined for this curve. It can be used exclusively as a method of comparing individual fragments of space. This is why graphic representation of the tension of impressions and emotional experiences occurring while moving along the time-space route is nothing but a symbolic and relative comparison of how successive scenic views are perceived by landscape watchers.

The horizontal axis of the graph is a time and linear scale with successive scenic view points along the route of the watchers. The vertical axis indicates tensions of impressions generated under the impact of systems with diverse spatial and significance values. Therefore, the graph of impressions is a graphic attempt to compare attractive features along the route with a given direction of wandering and a scale of the assumed starting point. The starting point constitutes a reference level for the subsequently appearing image values.

The process of assessing rural landscape with the use of the impressions curve consists of the following phases:

- The terrain being assessed is divided into zones with natural limits such as roads or zones being approximate squares one kilometer long and wide.

The assessing person moves along the route denoted by zone limits (roads or sides of squares), 
stops every 3-5 min (approx. 200-500 m), and assesses impressions in the points located on both sides of the route. The point-related range of the scale may be different. The analyses performed prove that a scale from 0 to 10 is the most adequate. The following basic parameters should be taken into consideration when assessing and rating scenic views by points from the selected points of observation: degree of landscape diversity, devastation level, level of landscape saturation with infrastructure (facilities), and composition harmony of all the elements occurring in landscape. When granting points for various degrees and conditions of those parameters, the assessing person should act according to how he or she feels and perceives a given landscape. The total assessment of landscape will be a sum of points granted for the four above-mentioned parameters: landscape diversity, devastation level, saturation with infrastructure (facilities), harmony of composition.

- A graph of impression curves that refers to individual routes is created: the horizontal axis is a measure of time (or distance), and the vertical axis indicates the number of points given in the assessment process.

- The graphs should mark those places which need aesthetic improvement of a varying degree (the values of points are given at a scale from 0 to 10 points):

- high degree aesthetic improvement is necessary for regions assessed below 4 points,

- medium degree aesthetic improvement is necessary for regions assessed between 4 and 7 points,

- no aesthetic improvement is needed for regions assessed above 7 points.

- From the graphs of the impressions curve graphs, the elements of the terrain under assessment should be transferred on its map, whilst the regions needing aesthetic improvement should be determined and grouped according to their levels of necessary improvement.

\section{The WIT Litwin's Method}

The WIT indicator was determined for three basic functions: agricultural, non-agricultural, and recreational. This indicator assesses the "value" of each selected area (village) and type of activities from the point of view of the set of assumed features.

In order to calculate landscape "values" correctly, it is very important to choose suitable features. This study applies a set of features that had already been used to evaluate spatial structures within the Basin of the Mszana River [15]. The WIT indicators were calculated based on those features. These indicators will make it possible to answer the question on the versatility of applying an equal input set for different (mountain and upland) landscapes in Poland. The set of features used to calculate WIT indicators and their short description was elaborated based on the postdoctoral (habilitation) thesis No. 225 [15].

The analysis of WIT was performed for the following types of activities:

- agricultural activity;

- non-agricultural activity;

- recreation.

The definitions of those activity types are as follows [15]:

1) Agricultural activity is an intensive, traditional animal and plant production run mainly to meet the needs of tourists, holiday makers and local population, under difficult, natural mountainous conditions. The usefulness of the area in question for agriculture is rather limited.

2) Non-agricultural activities include small industry, craftsmanship and services (including handicraft), food processing, transport, building industry, forestry fully subordinated to natural environment protection, based, first of all, on local raw materials, and adjusted to meet local needs, trade, gastronomy and educational, health, and cultural services.

3) Recreation and tourism refer to objects and facilities (including sports facilities) which serve tourism and recreation and are situated in a given place due to specific, valuable natural qualities and unique local traditions.

4) For each of the areas under investigation, a WIT indicator was determined as a sum of (2):

$$
\mathrm{WITa}=\mathrm{a}_{1} \mathrm{z}_{1} \mathrm{x}_{1}+\mathrm{a}_{2} \mathrm{z}_{2} \mathrm{x}_{2}+\mathrm{a}_{\mathrm{n}} \mathrm{z}_{\mathrm{n}} \mathrm{x}_{\mathrm{n}}
$$

where:

$X_{1} \ldots X_{n}-$ a set of normalized features of studied areas;

$a_{1} \ldots a_{n}-$ a set of "favourableness" weights determined on the basis of a test conducted by experts;

$z_{1} \ldots z_{n}-\mathrm{a}$ "significance" coefficient determining the significance of individual features.

A specific weight was attributed to each of the features while its impact on the area's usefulness for diverse farming functions was deter- 
mined as well as the coefficient determining its "significance" in relation to other features. Two rates were attributed to each of those features: a degree of "favourableness" of a given feature (favourable feature - non-favourable feature) and a degree of its 'significance' (significant feature insignificant feature) [16].

The "favourableness" of a feature is its positive/negative impact on the usefulness of a given terrain for a specific activity (for example: a high soil quality indicator is, of course, a favourable feature favouring agricultural activity). The "significance" of a feature refers to its importance for a given activity in the given range of potential of such a terrain (for example: a high number of relatively new buildings are a favourable feature, yet, not as significant for the agricultural activity as the mean quality indicator of soil in the particular village).

A test by experts was applied to determine the "favourableness" weights [15]. Under this test, thirty specialists in the field of spatial management, environmental protection, agriculture, and non-agricultural activity filled in a questionnaire containing all the features as named above. The features were assessed on a point scale, with the following assumptions:

- -2 points were given when the feature was "highly unfavourable",

- - 1 point was given when the feature was "unfavourable",

- 0 points were given when the feature was "neutral",

- +1 point was given when the feature was "favourable",

- +2 points were given when the feature was "highly favourable".

In order to determine the degree of "significance" of a given feature, a number from the range $0.3-1.0$ was assigned to each of them. Features of significant importance (e.g. soils quality indicator for agriculture) were marked by the value of 1 . The calculations were performed according to the formula (1). Three indicators were obtained (WIT1 - for agricultural activity; WIT2 - for non-agricultural activity; WIT3 - for recreation) for each of the 10 villages in the investigated area.

Only comparable features were included in the calculations; for example: for the feature No. 9 (number of buildings), it was assumed that its value was the ratio of the number of buildings to the total surface area of the whole village. The values of features incorporated into the formula
(1) were all referred to the mean value. That is, the mean value of a given feature was denoted as 1 , and the values of this feature for individual villages within the terrain studied were proportional to this mean value. For example: the village of Turów has 169 buildings and the area of this village is 741 ha, i.e. the development density equals 0.114 building/ha. The mean value is 0.201 . Thus, the value of 0.565 was used for calculations [16].

\section{AN OUTLINE OF THE HISTORY OF THE COUNTY}

Historical traces discovered within the area of the present-day town of Miechów and the nearby villages yielded an assumption that this place was the site of two prehistoric settlements. One settlement was to located the west of Miechów, at the foot of Stawna Góra in the river for of the Cicha and Miechówka; the second to the east of Miechów, close to the Jezdno and Stok Miejski springs forming the head of the Miechówka River.

The name "Miechów" was found, for the first time, was found in Book of the Brothers of the Order of the Holy Sepulchre. As a settlement, Miechów was most probably established at the times when the first tribal organizations were founded, i.e. at the end of the $11^{\text {th }}$ century, and, since then, it continued to develop. The place was founded by a man called Miechów who settled there when the state of the Vistulan tribe was in this territory. The history of the town and its neighbourhoods is closely connected with the history of the Order of the Holy Sepulchre until its dissolution in 1819.

In 1287, Miechów was completely destroyed by Tatars. A year later, owing to a new foundation charter granted to Miechów, the character of this town, its organization, system, and type of building development pattern changed entirely. Based on the German law, a new administratively separate and court-subordinated unit was created.

In 1287, Miechów was completely destroyed by Tatars. A year later, owing to a new foundation charter granted to Miechów, the character of this town, its organization, system, and type of building development pattern changed entirely. Based on the German law, a new administratively separate and court-subordinated unit was created.

The $14^{\text {th }}$ century was not a period of prosperity for the town of Miechów, so the town could not develop quickly and effectively. This was mainly 
due to the natural disasters, which decimated Poland in this century. During the Swedish invasions $(1655,1702)$, both the town and the monastery were robbed and destroyed. Also, the events of the Kościuszko Uprising exerted significant influence on the town of Miechów; in particular the Battle of Racławice in April 1974. In 1795, one year after the last partition of Poland, the Austrian army entered the town which marked the beginning of a new period in Miechów's history.

In 1809, after the creation of the Dutchy of Warsaw and with Poland being partitioned between three neighbouring countries, Miechów advanced to the position of a county town. Until the present day, with just several pauses, Miechów has continuously held the status of a county town.

During the January Uprising, the town was the scene of another battle, called the Miechowska Battle, lost by the Polish forces. This lost battle brought about heavy punishment on the residents of Miechów. Whilst the population of Miechów before the battle amounted to about 2000 people, after the fighting the town was burnt and destroyed with only 831 people staying alive. In the following years, several business-like co-operatives were established as well as some trade and craft workshops. Moreover, a railway line was built.

Prior to the administration reform of 1999, the area within the current powiat of Miechów belonged to the Kieleckie Voivodeship. In 1999, Miechów again became the seat of local administration authorities of the Małopolskie Voivodeship [according to the Local Development Plan of the Powiat of Miechów in the years 2004 to 2006 dated 09/06/2004].

\section{THE PROFILE OF THE TERRAIN STUDIED}

The village of Pojałowice belongs to the district of Miechów and county of Miechów in the NW part of the Province of Małopolska (Fig. 1).

From the geographic and physical point of view, this area is part of the Upland of Małopolska region. The county itself lies within the range of the Upland of Miechów. The town of Miechów lies approximately $40 \mathrm{~km}$ to the north of Cracow (Cracow is a seat of the provincial authorities) and is about $80 \mathrm{~km}$ to the south of Kielce. The main communication and transport axis of this district is the public E77 highway going from Chyżne (Poland's southern border checkpoint) through Kraków, Warsaw, and, then, on to Gdańsk on the Baltic shore.
The area of the district including the town of Miechów is 14,837 ha. The district is divided into 34 'solectwa' (the lowest units of the local administration in the Polish villages).

Pojałowice is a village situated in the southern part of the district. The area of the village of Pojałowice is 550 ha. The neighbouring villages, being also 'sołectwa', of Pojałowice are: to the east: Glinica, Sławice Szlacheckie, and Wymysłów; to the west: Zarogów and Nasiechowice (Fig. 1).

\section{Natural conditions}

Agriculture is based on land, which belongs to the basic production factors. Therefore, it highly depends on the specificity of natural environment conditions. This is not only reflected in the level of achieved production effects, but also affects the efficiency of applied production factors applied, that is labour and capital.

It is possible to adjust plant production to natural characteristics of diverse biotopes and to ensure its growth provided due investigations and evaluating studies are performed [13].

Soil is the key element of natural environment. Soils build both a biotope and a source of plant nutrients. Besides the soil, natural conditions of agricultural production depend and are influenced agro-climate, relief, and water conditions. All those elements are interrelated and influence one another as they jointly create production space for agriculture [20].

\section{Soil conditions}

Soil is the surface layer of the Earth's crust (lithosphere) transformed by biological, physiographic, and anthropogenic factors during the soil formation process and suitable for plant production [13].

Soils within the community of Miechów possess very high and high natural and economic (agricultural) values. This statement is proved by the local valued of the Agricultural Production Space Indicator that equals 90.8 points (according to the Institute of Soil Science and Plant Cultivation in Puławy).

The assessment points granted to individual elements of the environment in the terrain investigated are listed in the description of the local spatial management plan developed for this gmina on the basis of "Agricultural valorization of 


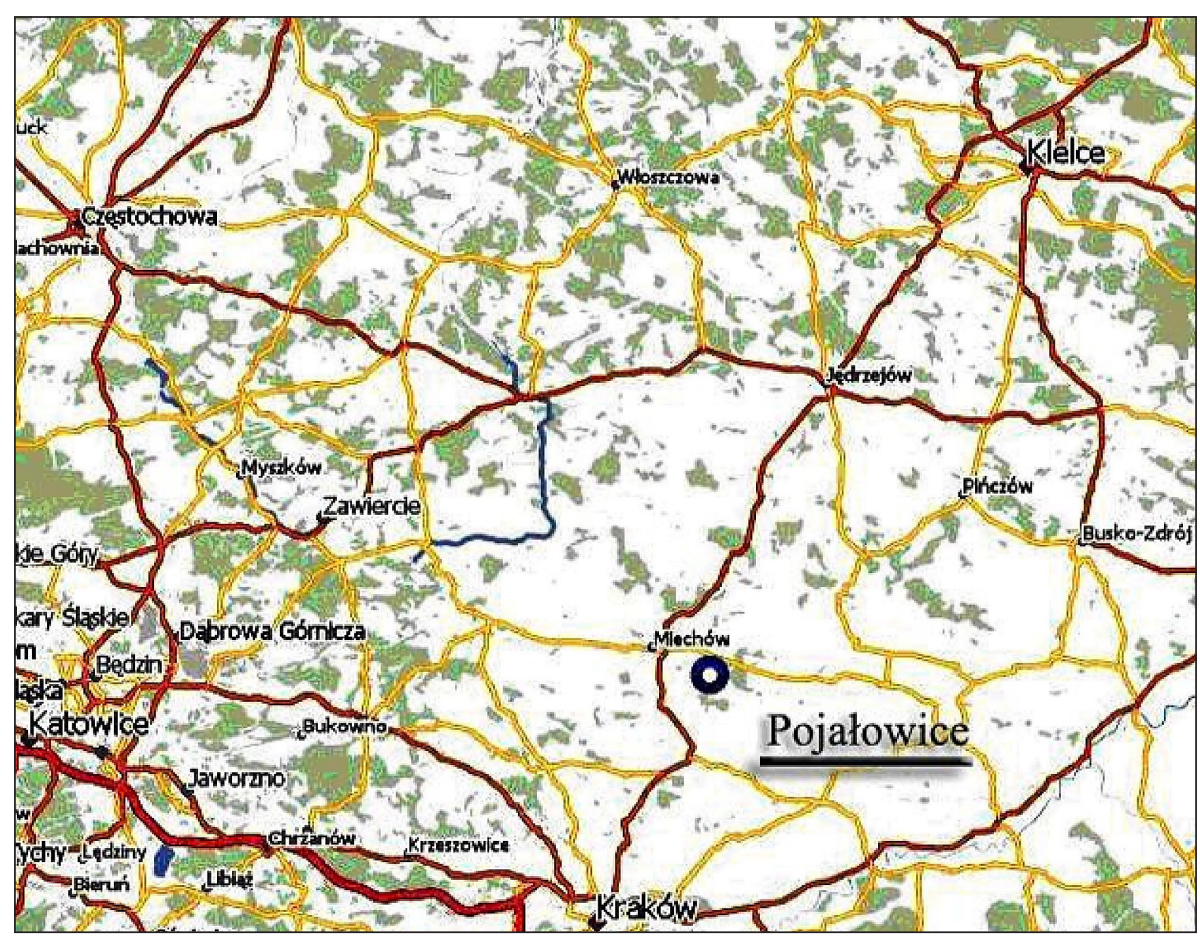

Figure 1. The location of the village of Pojałowice on the map of Poland

production space in Poland by individual gminas. They are as follows:

- quality and agricultural usefulness - 73.4 points,

- agro-climate - 11.6 points,

- configuration and surface features of the area $-1, .8$ points,

- water conditions -4 points.

The geological bed in this community is made up of Cretaceous deposits covered by a loess layer. This is why, the soils in this area reveal a characteristic mosaic arrangement. Loess was washed off from hilltops, hillsides, and other areas exposed to erosion, Cretaceous subgrade was uncovered and dark, grayish-brown, humusrich soil called redzina were formed. In the land depressions, there are diluvium deposits, and in the valleys - alluvial soils (warp soils).

The following soils origin from the loess deposits: pseudo-podzolic soils, brown soils, blackearth (chernozem), and black soils.

The profile of soils agriculturally utilized in the village of Pojałowice was studied and developed based on the 1:5000 soil-agricultural map.

Beside homestead features and typological data regarding soils, the soil-agricultural maps contain synthetic information on the depth of the soil layer (thickness) and soil graining at the individual profile levels of soils. The basic groups shown on the soil-agricultural map involve soils classified according to their agricultural usefulness; such groups constitute various types of homesteads within a given agricultural production space.

Groups of soils are named after the indicator plants, which have satisfactorily adapted to the characteristic conditions of a given farm (homestead); such groups consist of complexes of soils showing similar agricultural usefulness, geo-morphological characteristics (location in a given terrain), water properties, fertility, and productivity.

Brown soils predominate in the village of Pojałowce; they contain essential humus deposits, are biologically active, and show good physical properties. They mainly occur in the northern and central part of the village, some patches are in the eastern and south-western part thereof.

The calcareous soils cover large areas, too. They are potentially fertile soils, although hard when cultivated, especially when they are either too wet or too dry. Their agricultural value depends on the soil profile depth (thickness) and mechanic composition. The calcareous soils are present in the southern part of Pojałowice and, locally, in the north of the village. In the central part of the village, warp soils (alluvial soils) were formed; they are utilized as grassland. Locally, black-earth (chernozem) and black soils occur; they are soils showing a high production potential, and give high yields with all cultivated plants. 
One part of the profile of soils is a description of soil-agricultural complexes from the point of view of their natural values and agricultural usefulness.

In Pojałowice, there are distinguished 4 arable soil complexes: 1, 2, 3, and 8, and 3 grassland complexes: $1 \mathrm{z}, 2 \mathrm{z}$, and $3 \mathrm{z}$.

Complex 1: a very good wheat complex encompassing soils of the highest ecological and practically profitable values. They are deposited in flat and slightly rolling terrains. They are suitable to grow wheat, sugar beet, and vegetables. They are classified as soil fertility classes I and II. They are subject to strict legal protection in order to keep them for agricultural purposes only. Complex 1 occurs as soil patches in the central part of the village.

Complex 2: a good wheat complex comprising soils having a mechanic composition similar to soils under the complex 1, but they are deposited under the worse physiographical conditions with the worse air-water relations. They are classified as soil quality classes IIIa and IIIb; they are also protected for agricultural use. Soil complex 2 is present in the northern and central part of the village, and some small patches of those soils are found near the southern and eastern boundary of the village.

Complex 3: a defective wheat complex. The soils under this complex are typologically classified as calcareous soils; they are deposited on smaller or greater slopes. They are classified as soil fertility classes IIIb, IVa, and IVb. The terrains with this complex are characterised by valuable, scenic landscape qualities; thus, they constitute an inseparable element of the agricultural panorama of the Upland of Miechów. Complex 3 occurs locally in the form of patches within the area of the entire village.

Complex 8: strong cereal \& fodder complex; a small patch of it is located in the central part of Pojałowice.

The grassland complexes cover areas with dusty alluvial soils formed in river valleys and on their edges. They belong to soil fertility classes II, IV, V, and VI.

The agriculturally unsuitable areas (AUA) and wasteland (WL) are terrains that cannot be agriculturally utilized because of steep slopes or because they are either post-mining or marshy lands; their natural value is diversified, but their surface area is not large. In Pojałowice, they are in the form of small patches in the central and eastern part of the village.
To determine the usefulness of soils to agricultural production, it is necessary to assess their quality classes. In Pojałowice, the arable lands are mainly covered by soils from the quality classes IIIa and IIIb.

There are many soils from the soil quality class IVa and IVb. In the central and southern part of this village, there are also soils of the class I and II.

On the soils of the types as specified above, it is possible to grow practically the majority of the plant species. Of course, those soils are also subject, to a greater or lesser extent, to erosion and degradation processes causing the biological activity of the soil environment to decrease, the productivity of the soils to worsen, and the soil cover to be ruined. Usually, the degradation processes of the loess soils, initiated by water erosion, occur on slopes showing gradients above $6^{\circ}$. In the village of Pojałowice, the majority of terrains have fields arranged along the hill slopes, thus, the erosion phenomena are greater here. Therefore, it can be assumed that about $70 \%$ of the arable lands are potentially endangered by this process, and approximately $20 \%$ is subject to strong and very strong erosion, which is a very destructive process. For that reason, amelioration and agro-technical measures in those terrains are highly recommended.

\section{Climatic conditions}

With regard to the climate, the most essential factors differentiating the agricultural space are inherent thermal and pluvial conditions. For a given mechanic composition of soils, those conditions also determine humidity conditions in those soils. Under the temperate climate (with a sufficient volume of rainfall), the length of vegetation period can be a satisfactory measure of agro-climate, i.e. the number of days with average daily temperatures exceeding $5^{\circ} \mathrm{C}$. The ambient temperatures control the length of plant developmental phases, thus, they control the vegetation period and indirectly impact the plant crop yield [13].

The district of Miechów is situated in the climatic upland region of the western part of the Province of Małopolska, with very apparent influences of the continental climate. The average annual air temperature is $7.1^{\circ} \mathrm{C}$. The coldest month is January $\left(-7^{\circ} \mathrm{C}\right)$, and the warmest $-\mathrm{July}\left(+17^{\circ} \mathrm{C}\right)$.

It is possible that with a richly diversified relief features, separate, quite different micro- 
climatic conditions may be formed side by side, in small areas. Areas having different slope gradients and diverse expositions receive unequal quantities of solar energy. Additionally, diversified thermal conditions caused by diversified relief make soils freeze irregularly [13].

In Pojałowice, the topoclimate with slopes having southern, southern-western, western, and eastern exposures prevails. The characteristic features of this type of climate are the following: very good thermal and insulation conditions, good air circulation, low occurrence of fog, and a shorter period of snow cover. This topoclimate is very favourable for people and conducive to the development of housing estates and of orchards. Another type of the topoclimate in this region is a topoclimate typical for flat areas, with good and average solar and thermal conditions. While reviewing climatic phenomena, it can be said that the conditions favour the economic activity of people. The area of the community of Miechów belongs to warm regions with moderate climate.

It is possible that in a sculptured terrain, separate, quite different micro-climatic conditions may be formed side by side, in small areas. Terrains having different slope gradients and diverse expositions receive unequal quantities of solar energy. Additionally, diversified thermal conditions owing to the sculptured terrain cause the soils to freeze irregularly [13].

In Pojałowice, the topoclimate with slopes having southern, southern-western, western, and eastern exposures prevails. The characteristics of this type of climate are: very good thermal and insolation conditions, good air circulation, low occurrence frequency of fog, a shorter period of lingering snow cover; this topoclimate is very favourable for the people and is conducive to the development of housing estates and orchards. Another type of the topoclimate in this region is a topoclimate typical for flat areas, with good and average solar and thermal conditions.

While reviewing the climatic phenomena, it can be said that the conditions favour the economic activity. The terrain of the district of Miechów is considered a warm region with a temperate climate.

\section{RELIEF AND CONFIGURATION OF THE TERRAIN}

The relief and configuration of the terrain essentially impacts, both directly and indirectly, the quality of agricultural production space. Indirectly, the relief and configuration influences other elements of environment, in the first place: the way soils are shaped and their agricultural usefulness, next, climatic conditions (micro-climate) and water conditions [13].

The district of Miechów is within the Upland of Miechów. This Upland is part of a macro-region called 'Niecka Nidziańska' (Basin of the Nida River), which is a southern part of the Middle-Małopolska Upland.

The Upland of Miechów is morphologically diversified. Within it, there are abundant hillocks and longitudinal depressions called vales. They divide the upland into hillocks and hummocks. Although the region has typical features of an upland, geographically it is a depression. In the vicinity of the Miechów Mountains, there are the highest hills of max $380 \mathrm{~m}$ a.s.1., and the hills of $340 \mathrm{~m}$ a.s.l. are in the western part of the district, in the region of Miechów Forest. To the East, the district's terrain goes down; however, its hillyupland character is maintained. Amidst the hills, there are vales, running from the east to the west; they are of the tectonic origin.

Several river valleys (Szreniawa, Mieczówka, Gołczanka, Piotrówka, Zarogówka, and Kalinka rivers) add variety to this upland landscape in the district of Miechów. Those valleys are characterized by a strong asymmetry of their slopes. The eastern slopes are high and steep whereas the western - mild.

The morphology of the terrain under study reflects an underground geological structure.

There are three block-fold structures. The deeper layers of hills are composed of harder Cretaceous deposits covered by a soft loess layer. They form an upland landscape with deep river valley dissections. The diversely concentrated relief and configuration of this terrain is composed of exposed, steep Cretaceous slopes. In the central and eastern part of this district, there are no forests, thus, erosion processes in the soils are accelerated here. In the river valleys, the alluvialdeluvial deposits of silts, clays, and sands lie.

Concluding: owing to the strong variety of the relief and configuration of this terrain, cultivating plants is not an easy task, especially mechanically. So it is necessary and recommended to apply suitable agro-technical techniques and measures. The character of the terrain's relief and configuration in the district of Miechów is a real obstacle for those who plan to develop some sites and to build there buildings/houses, etc. 


\section{WATER CONDITIONS}

The area of the district of Miechów is in the catchment basin of three rivers: Szreniawa, Nidzica, and Pilica. And, within the borders of this district, the following rivers and brooks have their springs: Cicha, a tributary of the river Miechówka, Piotrówka and Kalinka Brooks, the latter is a tributary of the river Nidzica. Kalinówka, a tributary of Pilica, is a river flowing across the northern-western part of the district. Local topographic (water) divides among the catchment's basins of the rivers as indicated above run along the crests of the hills separating them. No river flows across the village of Pojałowice.

In the Miechów Upland, there are underground waters in the Tertiary and Cretaceous deposits. There are two zones: the first one is an underground water zone connected with Quaternary deposits within the valleys' bottoms. The waters are in the sandy deposits and within the river silts. Here, there are shallow waters from the Quaternary era. Those waters are of no importance for water supply. Additionally, here there are underground Quaternary waters with no drilled wells to catch them, and underground Cretaceous waters fed by infiltrating rain and snow waters. Those waters are not for consumption since there are bacterial impurities in them. The second zone is an underground water zone in the upland terrains. Cretaceous deposits with fissures and pores appear within the Niecka Miechowska (Miechów Basin), and they are the main underground water reservoirs among all the Polish underground water reservoirs. The quality of these waters ensures that they are good for consumption. There are no combined sewerage systems for domestic wastewater and storm water in this district. Thus, it is indispensable to provide this village with sewage piping system and to construct new wastewater treatment plants.

\section{NATURAL AND LANDSCAPE QUALITIES}

The most important landscape \& spatial quality in the district of Miechów is the diversified shape of the terrain. Deep river valley cuttings and numerous ravines, flat bottomed accumulation valleys, through-shaped valleys extending into the hills, hummocks and hillocks add to the variety of the landscape. In this landscape, the ploughlands characteristic for agricultural areas prevails. The plant cover is relatively poor. However, rare flora species do occur here.

The most interesting plant cover within the entire Niecka Nidziańska is in the 'MiechowskoDziałoszycki OChK' district. Here, there are properly developed forest complexes in the form of a forest community: dry-ground forest communities and luminous oak-forests. The diversified relief and configuration of this terrain is responsible for the high floral changeability. Here, there are plentiful species of unique, rare and legally protected plants: Turk's cap lily, Whorled Solomon's seal, Rose of Provence, Daphne mezereum, Manchurian monkshood, Aconitum moldavicum, English ivy, ladybells, European bugbane, common columbine, orchids: broad-leaved helleborine, butterfly orchid, Veratrum lobelianum Bernh., and lungwort. Woodless Cretaceous hills and loess ravines are equally rich in diverse floral species growing amids xerothermic grasses and shrubby brushwood with legally protected plants.

The entire district of Miechów is included into various forms of natural protection programmes and schedules. In 1995, its entire area (however without the town of Miechów) was incorporated into the Miechów \& Działoszyce Area of Protected Landscape. The protection of surface waters in this Area was defined as the most important objective of nature protection. It was planned to recover river purity classes I and II for the rivers flowing across that Area. Here, the river valleys constitute inter-regional ecological corridors connecting Landscape Parks of the Ponidzie Region and Vistula River Valley with the valley of the Pilica River and with the Complex of Jurassic Landscape Parks. In the district of Miechów there is one nature reserve, namely "The Golden Hill" in Celiny Przesławickie.

Moreover, the nature protection scheme covered living nature monuments established. In the village of Pojałowice, the subject of this paper, two oaks and two lime-trees were established living nature monuments. The oaks grow on the roadside, within the premises of the Sosnówka forester's house, and the lime-trees - by the roadside shrine.

The following landscape assessment methods were applied to assess the landscape of the territory studied:

- Method of Optimal Utilization

- Wejchert's Method of Impressions Curve based on the aesthetic and scenic assessment of landscape. This method makes it possible 
to develop a map of regions having different needs for being aesthetically improved.

- Method of Terrain's Natural Elements (WNET) based on the assumption that the more natural elements a given terrain comprises, the more valuable its qualities are. This method allows for determining areas with better or worse than average ecological and landscape conditions.

\section{METHOD OF OPTIMAL UTILIZATION}

In order to determine optimal utilization of a given terrain, the Bajerowski's method was applied. Two propositions were made: 1 . based on the set of 56 features, it is possible to determine optimal function of a given area; 2 . such features reproduce fairly enough the impact of all the remaining features, also appearing essential from the point of view of generating an optimal function of the area.

An optimal function of the area can be determined by multiplying a transposed matrix of features generating optimal utilization of the area's features by an inventory matrix that registers the occurrence of the minor successive diagnostic features within the individual basic fields from the set as established above.

The inventory matrix takes on a form of zeroone matrix [1], where one stands for the occurrence of a given feature, and zero denotes that a given function does not exist at all.

In the matrix of features that generates an optimal utilization of the area, its individual elements inform what the impact power of this individual feature is to generate the need for initiating one of the above named functions (agricultural, silvicultural, recreational, rural settlement-related, and industrial) in the basic field under analysis. Figures with a minus (-) sign assigned to them denote a 'percent exclusion power', i.e. the power with which the occurrence of a given feature excludes the particular function to be introduced into the given basic field. Such a ,power” is construed as the intensity of needs for initiating a specific soil/ land utilization function.

During Phase I of the study, an analysis of the current state of utilizing soils/land was carried out; this analysis comprised the study on 56 characteristic features of the given area.

In order to accomplish the analysis, the entire area was divided into 175 squares with $200 \mathrm{~m}$ sides. The squares were classified according to the type of their utilization, and the following functions were grouped:

- Agricultural Function: arable lands;

- Agricultural Function - pastures;

- Agricultural Function - meadows;

- Silvicultural Function - production;

- Silvicultural Function - ecology;

- Recreational Function: individual recreation;

- Recreational Function: collective recreation;

- Recreational Function: with no right to develop the area (build houses, recreational facilities, etc.);

- Settlement Function;

- Infrastructure-industrial Function.

During Phase II, a matrix of optimal utilization of the given area was calculated. In order to receive such a matrix, the matrix of the current utilization of lands is multiplied by the transposed matrix of the set with 56 features, which generate the optimal utilization of a given area. An optimal function of the basic field is the function that receives the highest positive scoring figure that is the total of all the points granted to one of the functions.

\section{COMPARISON OF THE LAND USE PATTERN THE OPTIMAL STATE}

Based on the analysis results of the current and optimal states of land utilization, the transformation should be performed only in 12 basic fields.

A small number of necessary transformations show that the area of the village of Pojałowice is utilized according to the optimal function. This is possible because this village is a typical agricultural village with arable lands prevailing.

On the basis of the Figure 2, it is concluded that the agricultural function on arable lands is a leading function in both the current and optimal state of utilizing this area. Under the optimal state, as shown on Figure 2, a new settlement function appears, and the agricultural function disappears from the lands to be utilized as meadows.

During Phase III, the landscape assessment was analyzed by applying the following:

\section{WNET Method}

The basic claim in this method is that the more natural or close-to-natural (almost natural) elements are, the more valuable the landscape and ecological qualities are. 


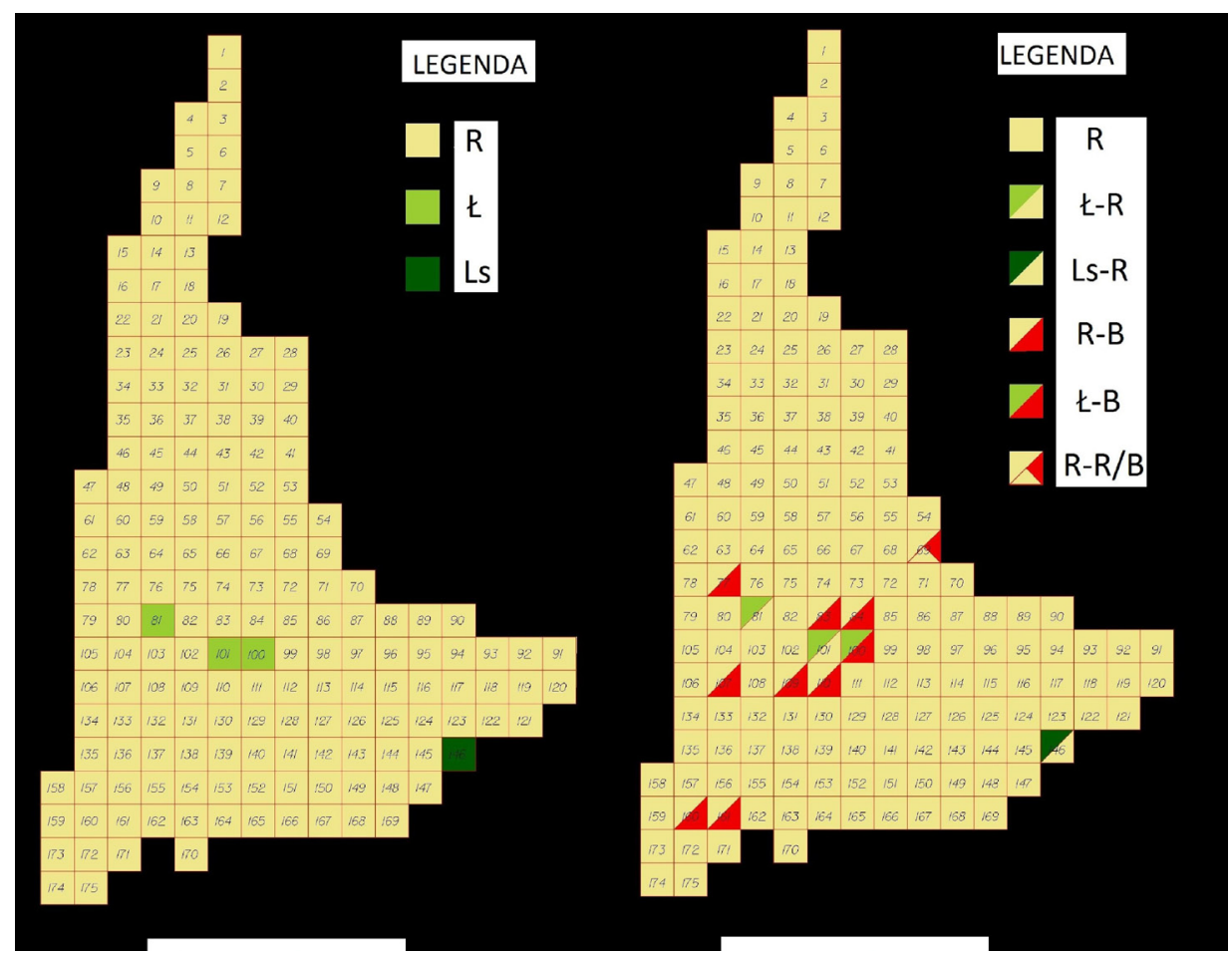

Figure 2. Current land use pattern state against the optimal utilization state

In this method, it is very important to select suitable diagnostic features the aim of which is to specify the number of the above mention elements in a given territory; also, they depend on the accessibility of source materials containing information we need.

The authors Cymerman and Koc, suggest that the following diagnostic features should be employed while determining the landscape qualities:

- Plant cover;

- Waters;

- Terrain Utilization Degree;

- Terrain's Surface Features;

- Landscape Protection;

- Soils.

The result of this method applied is a synthetic indicator incorporating the standardized features of the terrain. It is calculated as an arithmetic mean of all the standardized features of the district under assessment (3): $\mathrm{n}$

$$
W_{i}=1 / n \sum U_{i j}
$$

where: $W_{i}-$ synthetic indicator

$U_{i j}$ - standardized value of the $\mathrm{j}$-value for i-district

$n$ - number of features

Pursuant to the assumptions under this method, the area of the village was investigated with regard to the number of natural or close-to-natural elements. The selection of diagnostic features was made based on the examples cited by two authors: Cymerman and Koc. Parts of those diagnostic features were rejected since they were not present in the terrain investigated (the village of Pojałowice) or because it was impossible to obtain data necessary for calculations. The following materials were used while making necessary calculations: map of soils, map of utilization types, satellite images of the village of Pojałowice, and a study on the conditions and spatial management policies in the district of Miechów.

During Phase IV, the area of Pojałowice was divided into three research fields: northern field, central field, and southern field (Fig. 3, 4, 5).

The scope of agricultural land improvement works differs depending on the individual fields investigated. As for areas showing qualities higher than average $\left(W_{i}>0\right)$, all the agricultural land improvement works should focus on preserving and maintaining those lands, and, as for areas with qualities worse than average $\left(W_{i}<0\right)$, such works should aim at creating conditions to correct and improve those conditions.

Based on the investigations accomplished, it was possible to receive a 'Wi' synthetic indicator for each research field. This indicator determines the level of ecological or landscape qualities (Table 1). 


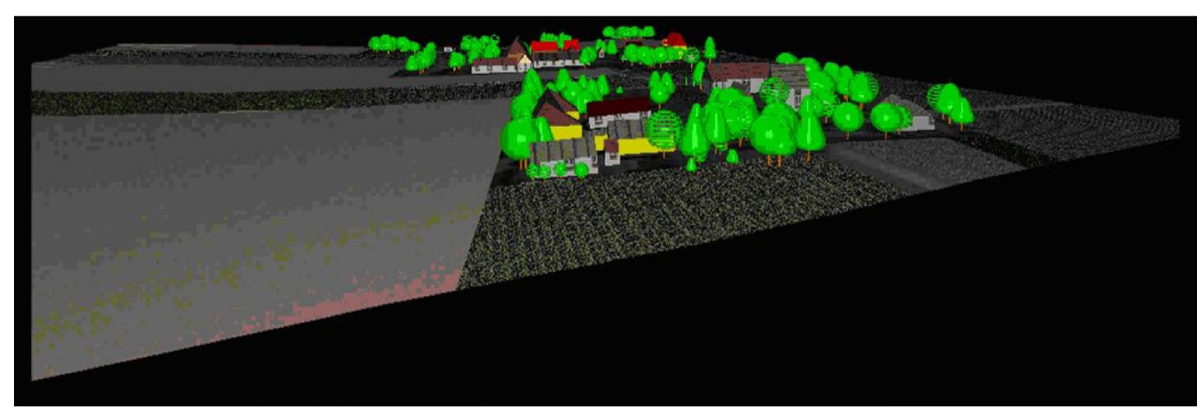

Figure 3. A fragment of the southern part of Pojałowice

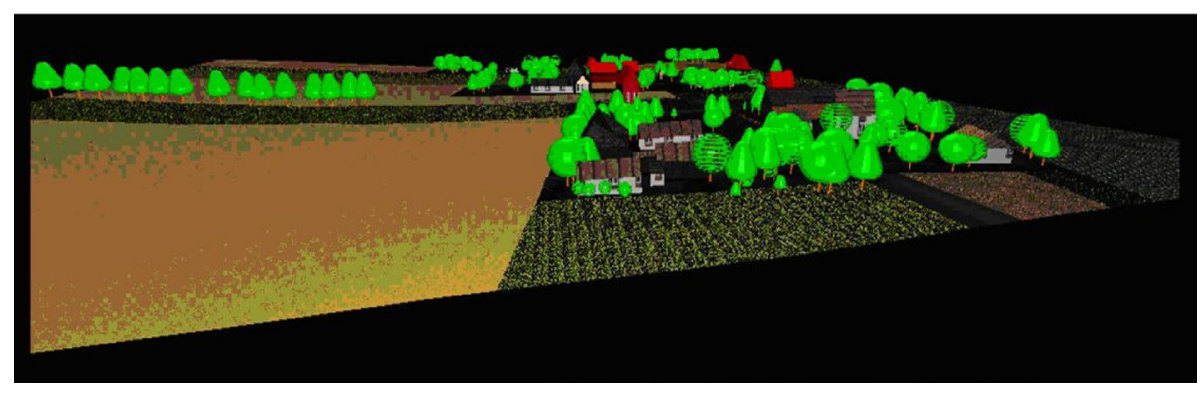

Figure 4. A fragment of the southern part of Pojałowice

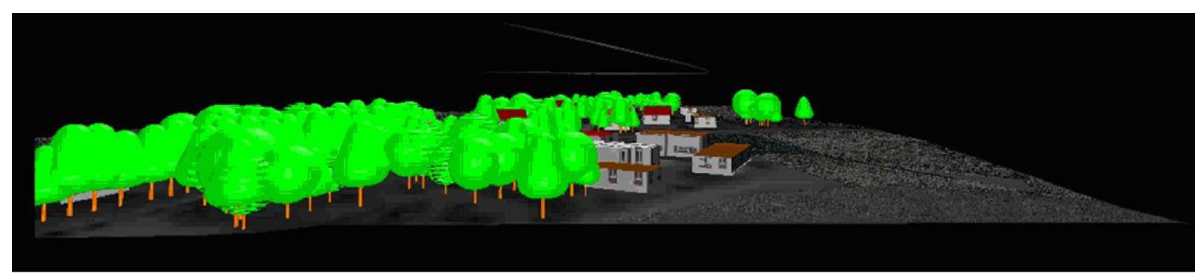

Figure 5. A fragment of the northern part of Pojałowice

Table 1. The level of ecological or landscape qualities

\begin{tabular}{|l|c|c|c|}
\hline & \multicolumn{3}{|c|}{ Research Field } \\
\hline Qualities & northern & central & southern \\
\hline $\begin{array}{l}\text { Landscape } \\
\text { qualities }\end{array}$ & -0.66114 & 0.599031 & 0.0621089 \\
\hline $\begin{array}{l}\text { Ecological } \\
\text { qualities }\end{array}$ & -0.68201 & 0.749671 & -0.0676599 \\
\hline
\end{tabular}

For the northern and southern part of Pojałowice, all the diagnostic features, average values and standard deviations were calculated. In order to calculate the $W_{i}$ indicators, a standardization procedure was performed.

The synthetic indicators pertaining to ecological qualities show that the central part of Pojałowice is ecologically the best. This fact is proved, mainly, by many complexes of green grass and their area. Standing and flowing waters play a significant role in this terrain, although they cover only an insignificant part of the total area, and other areas have neither standing nor flowing waters. The harmony of landscape in this terrain is rather disturbed, chiefly because large areas are developed and covered with buildings, and a dense road network is here.

The central part of Pojałowice shows good ecological and landscape qualities, especially in comparison to other parts of this village; in this part, there are green grass terrains, ditches, and watercourses, which add to the value and aestethics of the environs. Those important elements should be maintained in good shape, and the present and prospective managers should take care of their being constantly suitably harmonized with other features of the whole terrains. Here, there are also some negative features, such as a large number of developed areas of rather low aesthetic attributes, or a high quantity of roads (greater than in other parts of the village) that divide the natural landscape in this village into smaller zones. In Pojałowice, those elements are in a very poor physical condition, and this fact worsens the combined visual effect of the entire space. 


\section{Method of Impressions Curve by Wejchert}

The whole assessment procedure of landscape is divided into several phases. First, the area under analysis can be divided either into limited zones; the limits are formed by natural borders (such as roads), or into squares of $1 \mathrm{~km}$ sides. The limits of the zones are determined by tracks the landscape watcher wanders along (Fig. 6). On the both sides of the track, landscape observation spots are fixed, they are located every 3 to $5 \mathrm{~min}$ ute walk (i.e. the distance between them is about 200 to $250 \mathrm{~m}$ ), and the scale's range of points can be from 0 to 5 , from 0 to 10 , or from 0 to 100 . The following is taken into consideration when assessing the qualities of a given scenic view:

- degree of landscape diversity;

- level of landscape devastation;

- saturation by infrastructure;

- composition harmony of all elements.

- it is impossible to point out accurate guidelines on how to grant points since the assessment of the landscape qualities is purely subjective.

Next, graphs with impressions curves were plotted: distances were marked on the horizontal axis, and the number of points scored was shown on the vertical axis (Fig. 7, 8, 9).

On the graphs, those places that needed aesthetic improvement of various levels were marked:

- high level improvement was necessary for the regions scoring beyond 4 points;

- medium level improvement was necessary for the regions scoring within a range from 4 to 7 points;

- zero level improvement was necessary for the regions scoring more than 7 points.

In Table 2 points are shown for the first section of the entire track (Fig. 7), and on this basis, a graph of impressions curves was plotted.

When studying the graphs above, it is quite clear that even in such a small area, the diversity of landscape can be easily perceived. The range of diverse landscapes begins with the terrains having low qualities and it expresses the lack of any harmony in the composition. Thus, this part of the terrain has been scored 1 (the terrain is densely covered with buildings and with infrastructure facilities of more than 50\%). This range ends with the terrains scoring 8 owing to many valuable features and qualities therein. In the latter, there is one restored, historical shrine

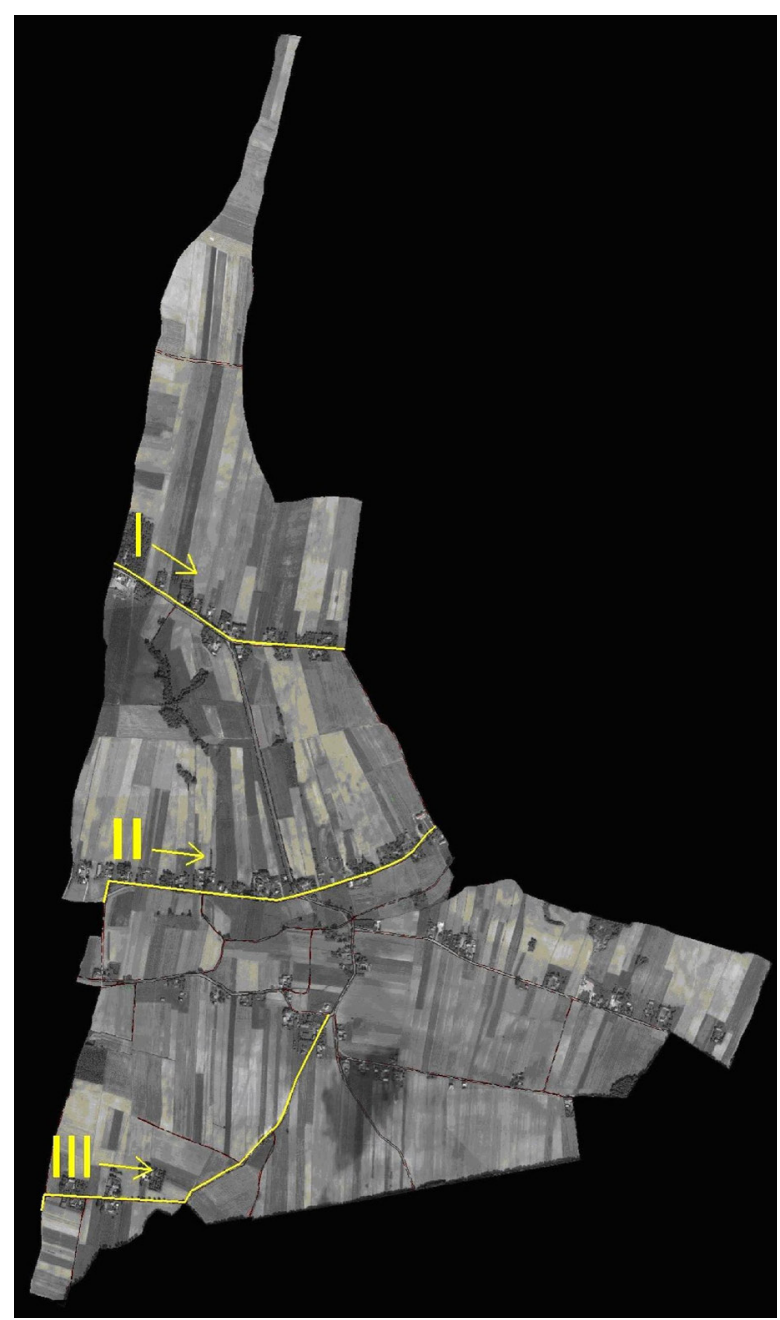

Figure 6. Observations tracks

surrounded by trees. It is worth stressing that the average assessment scoring of this terrain ranges from 4 to 7 points; however, all assessments approach 4 points. It means that this terrain needs a lot of agricultural land improving works to be done. Within this terrain, there is one interesting object: a watercourse that needs to be improved and regulated, and, next, adequately exhibited in the landscape.

For section II (Fig. 8), low assessments/low scoring was reported. On the left-hand side of this terrain, there are very many houses and many other farm buildings. The developed areas are located very close to the road, thus, the visibility of the panoramas is greatly reduced. Houses in the foreground are often anti-aesthetic, and the home-gardens are not well tended. The right-hand side of the road shows better aesthetic values in its beginning and ending parts, i.e. its aesthetic values are better since the landscape stretches out for arable fields, and, in its last part, for the forest and trees-grown escarpments. Table 3 contains 


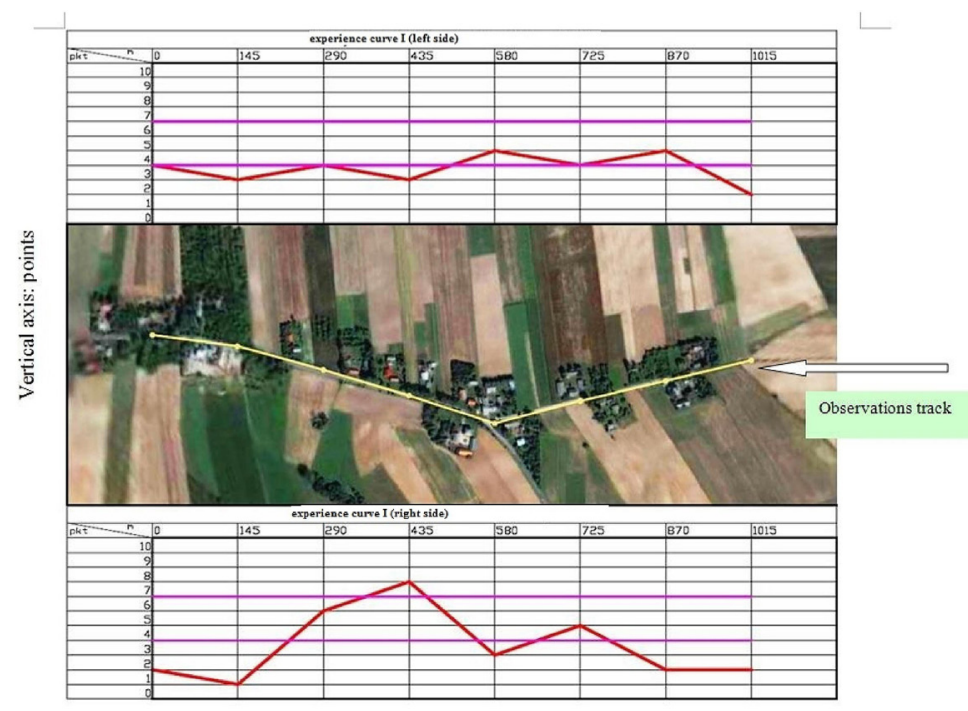

Figure 7. Impressions Curve I

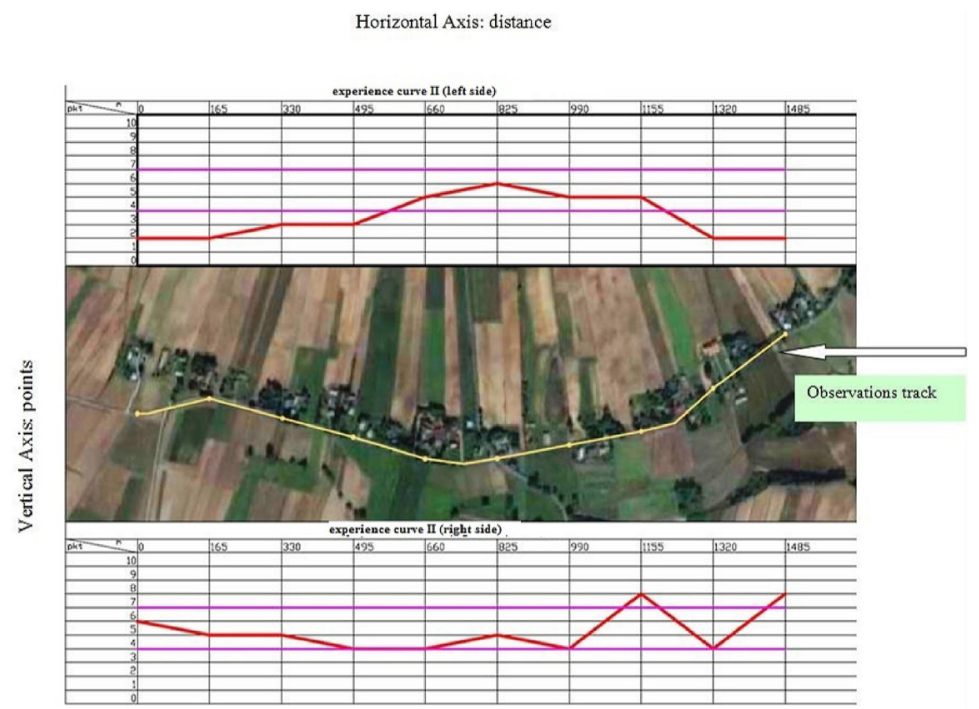

Figure 8. Impression Curve II

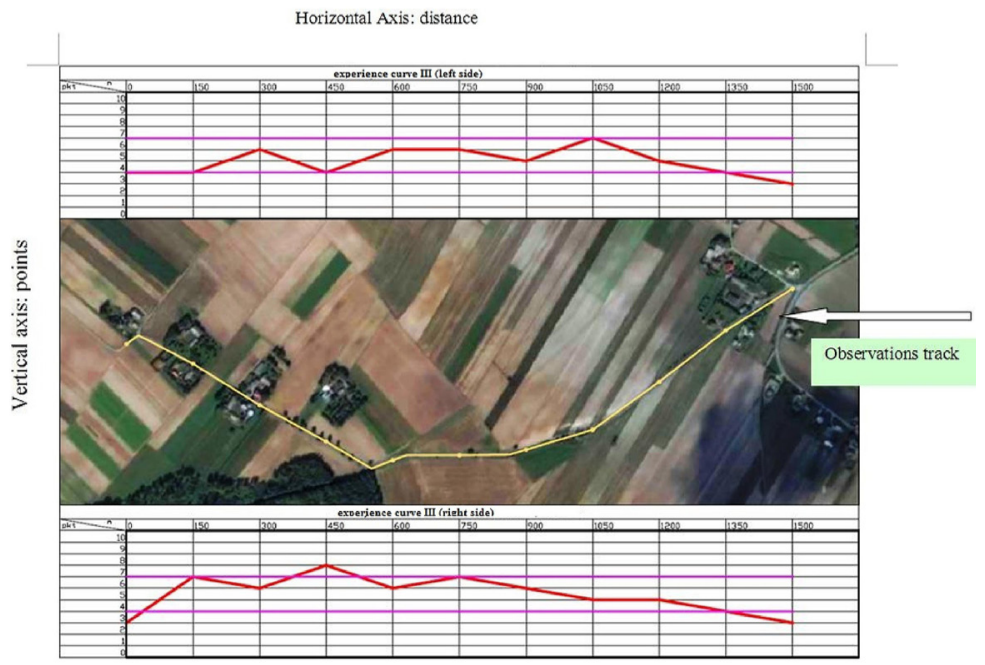

Figure 9. Impressions Curve III 
Table 2. Assessment of the terrain from the first Section of the track

\begin{tabular}{|c|c|c|c|c|c|}
\hline \multirow{2}{*}{ Side } & \multicolumn{5}{|c|}{ Distance [m] } \\
\cline { 2 - 6 } & 0 & 160 & 320 & 490 & 650 \\
\hline Left-hand & 4 & 3 & 8 & 4 & 3 \\
\hline Right-hand & 4 & 5 & 4 & 7 & 1 \\
\hline
\end{tabular}

Table 3. Assessment of the terrain from the Second Section (Section II) of the Track

\begin{tabular}{|c|c|c|c|c|c|c|c|c|c|c|}
\hline \multirow{2}{*}{ Side } & \multicolumn{10}{|c|}{ Distance $[\mathrm{m}]$} \\
\hline & 0 & 165 & 330 & 495 & 660 & 825 & 990 & 155 & 1320 & 1485 \\
\hline Left-hand & 2 & 2 & 3 & 3 & 5 & 6 & 5 & 5 & 2 & 2 \\
\hline Right-hand & 6 & 5 & 5 & 4 & 4 & 5 & 4 & 7 & 4 & 7 \\
\hline
\end{tabular}

the assessment scoring for this terrain, based on this Table, impressions curves were plotted.

From the impressions curve drawn for the left-hand side, it is clear that the average value did not reach 4 points; it means that on this side, agricultural land improving works are urgently needed. The right-hand side of the selected track has, absolutely, much better landscape qualities, although its scoring is within the range of points classified as an average need for introducing changes. On this side, one of the first works to be done should be hiding some elements, which negatively impact, simply worsen, visual impressions of the landscape, by growing high plants to close the front of the of the line of houses, buildings, etc.

The scoring of the scenic view from the third Section (Section III) of the track (Fig. 9) is shown in Table 4.

The investigations completed show that as for this terrain, its needs for agricultural land improving works are at an average level. However, in this place, the average values are close to the lower limit of the range of values. This terrain slightly rises and opens the horizon. Thus, visual effects are much nicer. On the left-hand side, there are single buildings, and on the right-hand side, the landscape is closed by the forest border. A medium voltage line was an essential element in this landscape, because it disturbed the harmony of the view at the forest. The tree-covered areas and the plant-covered escarpment overlook- ing the watercourse formed an interesting object in this landscape.

Based on the results of the investigations performed, it was possible to calculate the percent rate of areas needing change and improvement of the landscape compared to the total area of the terrain investigated (Fig. 10).

In the central part of Pojałowice, the terrains not requiring any improving transformations of their landscape constitute as little as $2 \%$. It means that here there exists a really very high need for introducing new solutions in order to create spaces with high aesthetic qualities in this area with an enormous landscape potential. There is as much as $73 \%$ of the area requiring medium-scale improving changes, for example: starting to grow plants and to organize and properly arrange the space. $25 \%$ of the total area is classified as the areas with high needs for introducing improvement measures since this area constitute vandalized and badly organized/arranged terrains. The old development (buildings \& other facilities) could be a very interesting place and attract visitors; instead, it becomes dilapidated and changes into a negative feature of the landscape's scenic view.

The graph representing the whole village shows that the terrain in the central part of Pojałowice has similar landscape conditions. The area in the village with no need for improving changes constitutes $12 \%$ of the total village area; but the percent rate of areas with a high need for improving works increased.

Table 4. Assessment of the terrain from the third Section (Section III) of the Track

\begin{tabular}{|c|c|c|c|c|c|c|c|c|c|}
\hline \multirow{2}{*}{ Side } & \multicolumn{9}{|c|}{ Distance [m] } \\
\cline { 2 - 20 } & 0 & 160 & 340 & 500 & 670 & 840 & 1000 & 1170 & 4 \\
\hline Left-hand & 5 & 4 & 4 & 5 & 3 & 4 & 5 & 6 \\
\hline Right-hand & 6 & 4 & 3 & 4 & 6 & 3 & 4 \\
\hline
\end{tabular}



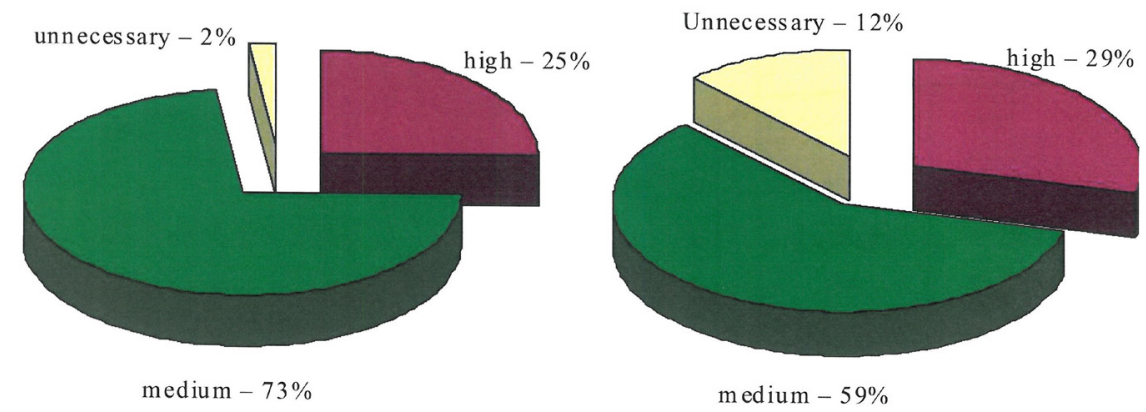

Figure 10. Percent rate of areas needing the improvement to the landscape

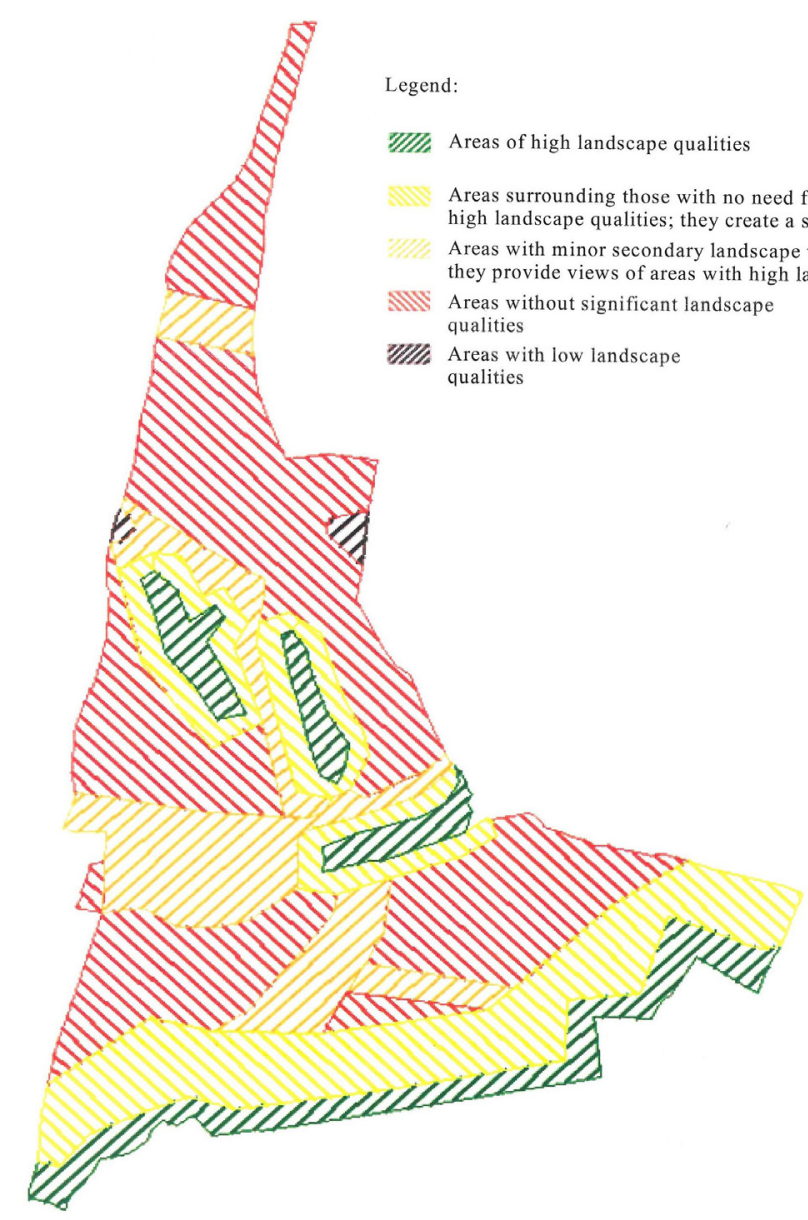

Figure 11. Map of regions showing different needs for being aesthetically improved

Based on the graphs of curves drawn up for the entire village of Pojałowice, a map of regions with different needs for aesthetically improving measures was made (Fig. 11). On this map, the areas showing low landscape qualities prevail because the landscape has been vandalized or it is very monotonic. In the central part, the terrains show high landscape qualities because, here, there are many tree-covered areas and escarpments with low plants growing thereon, and a watercourse surrounded by riverine brushes.
The analysis accomplished should be deemed a basis for specialists to introduce adequate agricultural land improving measures and to perform works that could improve the aesthetics of this rural landscape of the village of Pojałowice, for example: culturally valuable elements should be highlighted, and elements, which seem 'foreign' in this terrain, should be hidden. The potential concealed in this space should be properly utilized, for example, to create a cycleway or a place for relaxation and recreation as an alternative for the residents in Miechów. 


\section{CONCLUSIONS}

Based on the investigations of the current utilization state of soils allow for the following conclusions on the potential and limitations of the development of the region studied.

Development of any region is a dynamic process. The continually progressing changes are initiated by diverse factors and continuously impact the development, or, sometimes, the decline, of every region. Analyses based on data that seem to be current, not always give reasonable, fair results [15] .

It is necessary to remember that the results obtained have to be approached with certain reserve. Numerical values are given with a relatively high accuracy, however, they are only an attempt to measure 'the value' of a particular terrain.

A rational utilization of space, from both the nature-related and economic points of view, is the utilization employing, to the maximum extent, natural predispositions of a given terrain to specific utilization forms and methods, and, at the same time, prevents any degradation of this terrain [13].

Pursuant to the „Environmental Protection Law" (Polish Journal of Laws 2001, No. 62, Item. 627 with subsequent amendments), it can be concluded that the land (earth's surface) management should attempt to:

- rationally utilize land (earth's surface);

- maintain and preserve natural values;

- maintain the potential of land (earth's surface) for the production purposes;

- limit changes in the natural configuration and shape;

- maintain and preserve the soil quality at least at a standard level;

- maintain cultural values including archaeological gifts of culture.

Beside the assumptions, as indicated above, for the entire village of Pojałowice, it is also very important to promote alternative energy sources and to recommend their being in common use. A suitable investment policy is another condition for the proper management; always, a well-developed investment policy increases the economic attractiveness of a given region. Agricultural policy should emphasis the necessity to adjust farms to market economy requirements whereas social policy should stress the improvement of the living conditions and the quality of life of local residents.
As for the village of Pojałowice, the state of space utilization was analysed as were the landscape qualities, and, based on the analysis results, the following needs were determined:

- in some selected places, it is necessary to change the method of utilizing the space - including land;

- the engineering infrastructure and technical facilities need to be modernized and expanded;

- amids the fields, tree-covered patches should be arranged;

- roads must be renovated;

- private buildings and public edifices shall be refurbished;

New places for public use shall be created (such as playgrounds, parks, football pitches, cycleways, etc.);

- watercourses within the confines of the builtup areas shall be adapted for special purposes;

- building work repairs shall be undertaken on objects of historical value, as well as on other monuments;

- the housing estates shall be concentrated.

\section{REFERENCES}

1. Bajerowski T., 1996. Metodyka wyboru optymalnego użytkowania ziemi na obszarach wiejskich [Methods of selecting the optimal use of land in rural areas]. Wydawnictwo Akademii RolniczoTechnicznej, Olsztyn [In Polish].

2. Bajerowski T., Senetra A., Szczepańska A. 2000. Wycena krajobrazu - rynkowe aspekty oceny i waloryzacji krajobrazu [Valuation of landscape - market aspects of the assessment and improvement of landscape]. Wydawnictwo EDUCATERA Sp. z o.o. Olsztyn [In Polish].

3. Bajerowski T., 1991. Ocena, ochrona i kształtowanie krajobrazu wiejskiego, jako składnik programowania prac urządzenioworolnych [Assessment, protection and development of the rural landscape, as part of the programming work urządzenioworolnych]. Praca doktorska, Olsztyn [In Polish].

4. Bartkowski T., 1986. Zastosowania geografii fizycznej [Applications of physical geography]. Wydawnictwo Naukowe PWN, Warszawa [In Polish].

5. Bartkowski T., 1975. Nowy etap dyskusji nad pojęciem krajobrazu [A new stage in the discussion of the concept of landscape]. Czasopismo Geograficzne z. VI [In Polish].

6. Berninger O., 1975. Krajobraz i jego składniki 
[Landscape and its components]. W: Kształtowanie krajobrazu a ochrona przyrody [Shaping the landscape and nature conservation ] (pod red. K.Buchwalda). PWRiL, Warszawa [In Polish].

7. Bogdanowski J., 1973. Architektura krajobrazu [Landscaping]. PWN Warszawa [In Polish].

8. Böhm A., Architektura krajobrazu - jej początki i rozwój [Landscape architecture - its origins and development]. Skrypt dla studentów Wyższych Szkół Technicznych. Politechnika Krakowska im. Tadeusza Kościuszki Kraków [In Polish].

9. Böhm A., Patoczka R., 1998. Architektura krajobrazu - zbiór zadań z projektowania wstępnego [Landscaping - a set of tasks from initial design]. Politechnika Krakowska. Kraków, 1998.

10. Hopfer A., 1989. Krajobraz jako wizualny składnik środowiska i jego wrażliwość na projekty rozwojowe obszarów wiejskich [Landscape as a visual component of the environment and its sensitivity to rural development projects]. W: Materiały VI Ogólnopolskiego Seminarium Geograficzno-Rolniczego nt. Ekologiczne aspekty gospodarowania na obszarach wiejskich (na przykładzie Warmii i Mazur). Wydawnictwo Olsztyn [In Polish].

11. Kania J., 1998. Podstawy integracji europejskiej w aspekcie rozwoju obszarów wiejskich [Basics of European integration in the context of rural development]. Akademia Rolnicza, Kraków [In Polish].

12. Kondracki J., 1981. Geografia fizyczna Polski [Polish Physical Geography]. PWN, Warszawa [In Polish].

13. Koreleski K., 1993. Przyrodnicze podstawy użytkowania rolniczej przestrzeni produkcyjnej [Natural bases of use of the agricultural production]. Akademia Rolnicza, 993. Kraków [In Polish].

14. Langer H., 1978. Przyczynek do zagadnienia ekologicznego podziału krajobrazu [Contribution to the problem of the division of ecological landscape]. Przegląd Zagranicznej Literatury Geograficznej „Ekologia krajobrazu”, Warszawa.

15. Litwin U., 1997. Synergiczne uporządkowanie struktur krajobrazowych na przykładzie Kotliny Mszańskiej [The synergistic arrangement of landscape structures on the example Basin Mszańskiej]. Zeszyty Naukowe Akademii Rolniczej w Kraków, Rozprawa nr 225. Kraków [In Polish].

16. Litwin U., 2004 Weryfikacja metody wartościowania struktur krajobrazu z wykorzystaniem wskaźników istotności terenu [Verification of the method of valuation of landscape structures using the materiality of land]. Wydawnictwo Uniwersytetu Jagiellońskiego [In Polish].

17. Łuczyńska-Bruzda M., 1978. Ochrona krajobrazu [Landscape protection]. W: Ochrona i kształtowanie środowiska przyrodniczego [Protec- tion and management of the natural environment]. Red. W.Michajłow i K. Zabierowski T.II. PWN, Warszawa [In Polish].

18. Patoczka R., 1987. Studium systemu pojęć stosowanych w rewaloryzacji krajobrazu [Study of system concepts used in landscape restoration]. W: Materiały opracowane w ramach problemu międzyresortowego nr 1.6. PAN, Kraków [In Polish].

19. Przewoźniak M., 1984. Morfostruktura krajobrazu województwa gdańskiego [Morfostruktura landscape Gdańsk Province]. Przegląd Geograficzny t.LVI z. 1-2 [In Polish].

20. Rudnicki H., 1995. Gospodarka ziemią rolniczą w Polsce [Economy agricultural land in Poland]. Wydawnictwo Uniwersytetu Marii CurieSkłodowskiej, Lublin [In Polish].

21. Schmithusen J., 1978 Pojęcie i określenie treści krajobrazu jako obiektu badań geografii i biologii [The concept and definition of the content of landscape as an object of study of geography and biology]. Przegląd Zagranicznej Literatury Geograficznej „Ekologia krajobrazu”, Warszawa.

22. Senetra A., 2015. „Las jako istotny komponent przestrzeni w aspekcie opracowywania map wartości krajobrazów wiejskich". SYLWAN 159/9, str. 757-766

23. Smoleński J., 1978,1912. Krajobraz Polski [Polish landscape]. PWN Warszawa [In Polish].

24. Stola W., 1993. Struktura przestrzenna i klasyfikacja funkcjonalna obszarów wiejskich Polski [Spatial structure and functional classification of rural Polish]. Wydawnictwo PAN, Warszawa [In Polish].

25. Szczęsny T., 1977. Ochrona przyrody i krajobrazu [Nature and landscape protection]. PWN, Warszawa [In Polish].

26. Szczęsny T,. 1977. Ochrona przyrody i krajobrazu [Nature and landscape protection]. PWN, Warszawa [In Polish].

27. Witek T., 1981. Valorization of agricultural production space in Poland by gminas (IUNG), Puławy

28. Wodziczko A., 1946. Ogólne zasady uprawy krajobrazu w Wielkopolsce w celu podniesienia produkcji rolnej [General rules for growing landscape in Wielkopolska in order to increase agricultural production]. Maszynopis na zlecenie Regionalnej Dyrekcji Planowania Przestrzennego w Poznaniu, Poznań [In Polish].

29. Wolski P., 1988. O pojęciu krajobrazu i jego stosowaniu w dziedzinie architektury krajobrazu [The notion of landscape and its application in the field of landscape architecture]. Problemy Architektury Krajobrazu tom I, Wydawnictwo SGGW-AR, Warszawa [In Polish]. 